\title{
Penicillium Glabrum Acted as a Heat Stress Relieving Endophyte in Soybean and Sunflower
}

\author{
Ismail $^{1}$, Muhammad Hamayun ${ }^{1 *}$, Anwar Hussain ${ }^{1}$, Amjad Iqbal², \\ Sumera Afzal Khan ${ }^{3}$, Sarah Gul ${ }^{4}$, Hamayoon Khan ${ }^{5}$, Khushnood Ur Rehman ${ }^{6}$, \\ Hamida Bibi ${ }^{7}$, In-Jung Lee ${ }^{8 * *}$ \\ ${ }^{1}$ Department of Botany, Abdul Wali Khan University Mardan, Mardan, Pakistan \\ ${ }^{2}$ Department of Food Science \& Technology, Abdul Wali Khan University Mardan, Mardan, Pakistan \\ ${ }^{3}$ Centre of Biotechnology and Microbiology, University of Peshawar, Pakistan \\ ${ }^{4}$ Department of Biological Sciences, FBAS, International Islamic University, Islamabad, Pakistan \\ ${ }^{5}$ Department of Agronomy, University of Agriculture Peshawar, Peshawar, Pakistan \\ ${ }^{6}$ Department of Botany, Islamia College University Peshawar, Peshawar, Pakistan \\ ${ }^{7}$ Department of Soil and Environmental Sciences, University of Agriculture Peshawar, Peshawar, Pakistan \\ ${ }^{8}$ School of Applied Biosciences, Kyungpook National University, Daegu 41566, Korea
}

Received: 28 July 2020

Accepted: 18 October 2020

\begin{abstract}
High temperature is one of the compelling ecological stresses faced by the plants owing to anthropogenic activities of mankind. Recently, endophytic fungi are considered to be a novel tool to counteract the consequences of thermal stress in crops. Owing to the problem, we isolated fungal endophytes from Dryopteris blanfordii and their growth favoring potential in rice seedlings. Endophytic fungi have the proficiency to secrete plant growth stimulating secondary metabolites that help the host plants to restore growth under harsh environments. The isolated Penicillium glabrum (DryR30) helped the host plant species, i.e. Glycine max L. and Helianthus annuus L. under thermal stress. P. glabrum associated with G. max and H. annuus exposed to $40^{\circ} \mathrm{C}$ not only boosted their host growth attributes (total biomass, plant height and chlorophyll contents), but also significantly curtailed the synthesis of reactive oxygen species and lipids peroxidation. Moreover, the abscisic acid (ABA) and proline concentrations were significantly reduced, while the accumulation of ROS-degrading enzymes, such as catalase (CAT), peroxidase (POD), ascorbic acid oxidase (AAO), glutathione reductase (GR) and superoxide dismutase (SOD) were increased in P. glabrum-associated crops. Additionally, the protein,
\end{abstract}

*e-mail: hamayun@awkum.edu.pk

**e-mail: ijlee@knu.ac.kr 
lipid and sugar contents in tested plants were also improved. These stirring findings suggest that P. glabrum can be applied to food crops as a thermal stress alleviation tool.

Keywords: endophytic fungi, P. glabrum, Dryopteris blanfordii, thermal stress, reactive oxygen species, antioxidants

\section{Introduction}

Better diet and tenable nutrition, are the two vital needs of human for which man is in incessant fight, while climate change makes these goals more challenging for mankind. Heterogeneity in the edaphic and climatic environments of a complex habitat regulates the topographical dispersal outline of vegetations [14]. Plants growing under stress display some level of adaptability to stressful conditions [5-8]. At high temperature; loss in yield and other growth parameters of crop species are expected $[9,10]$. Moreover, proteins, lipids and chlorophyll molecules can be degraded by the oxidative action of ROS (hydroxyl radical $(\mathrm{OH})$, singlet oxygen $\left({ }^{1} \mathrm{O}_{2}\right)$, hydrogen peroxide $\left(\mathrm{H}_{2} \mathrm{O}_{2}\right)$ and superoxide $\left(\mathrm{O}_{2}^{-1}\right)[5,6,11-14]$.

To evade oxidative losses, plants have self-activateddefense-mechanisms (SADMs), i.e. comprised of antioxidant systems and compatible osmolytes [15]. Another procedure adopted by plants, is the transport and storage of toxic molecules and ions to less sensitive tissues [16]. Antioxidant scheme adopted by plants, comprise enzymatic and non-enzymatic machineries that work together to detoxify ROS species. Catalase (CAT), peroxidase (POD), superoxide dismutase (SOD) and glutathione reductase (GR) represent enzymaticantioxidant system. On the other hand, ascorbic acid, tocopherol and some secondary metabolites symbolize the non-enzymatic-antioxidant system of plants [17].

Different biotic and abiotic stress causes accumulation of proline and phenolic compounds in higher plants. Proline and phenolics function as ROS scavengers, osmolyte, proteins and membrane stabilizer, and buffer of cellular redox reactions [5, 6]. Proline also helps in the maintenance of cellular-acidosis, protein-compatible-hydrotrope and balancing the ratio of $\mathrm{NADP}^{+} / \mathrm{NADPH}$ essential for cellular metabolism. Brakedown of proline after stress, generates huge amount of reducing agents that are used for ATP synthesis in mitochondrial oxidative phosphorylation. ATPs are then used in stress retrieval and in the refurbishment of already done damages [18]. Phenolics are known to function as antioxidants, herbivores restrictors, and has the ability to attract plant pollinating insects [19]. Besides, plant hormones, such as abscisic acid (ABA), jasmonic acid (JA) and salicylic acid (SA) have a role in diverse ecological stresses as signaling chemicals [20-25]. Among these phytohormones, ABA help in opening and closing of stomata during drought and thermal stresses [26]. ABA also has a role in seed germination, maturation and senescence of vascular plants, including Arabidopsis thaliana [27].
Endophytic fungi, such as Aspergillus flavus [5], Aspergillus japonicas [6], Penicillium roqueforti [28], Trichoderma reesei [29] are asymptomatic beneficial microbes that reside inside the plant tissues on the permanent basis. Endophytes and rhizospheric microbes are known to have a role in the restoration of the host growth under various abiotic and biotic stresses. The endophytes provide resistance against stresses, accelerate mineral absorption and improve biomass of their host plant [30, 31]. Without endophytic fungi and rhizospheric microbes, plants are more susceptible to ecological constrains, like high temperatures, drought and salinity [5, 32-35]. Aspergillus sydowii was found to have the capability to tolerate heavy metals (HMs) toxicity by modifying the activities of CAT, GR, SOD and the contents of malondialdehyde, proline and thiol [36]. The present work was performed in an attempt to investigate the role of $P$. glabrum as a stress adaptive tool in $G$. $\max$ and $H$. annuus during heat stress.

\section{Materials and Methods}

Experiments were conducted at the Department of Botany, Abdul Wali Khan University Mardan, Khyber Pakhtunkhwa, Pakistan. Oryza sativa L. seeds, Fakhre-Malakand (commercial variety) were attained from the Agriculture Research Station, Mingora, Swat, Pakistan. O. sativa seeds were grown in pots containing $30 \mathrm{ml}$ of water-agar medium $(0.8 \% \mathrm{w} / \mathrm{v})$. The pots were placed in a growth-chamber set at day light regime of $14 \mathrm{~h}, 28^{\circ} \mathrm{C} \pm 0.3$ (day); and $10 \mathrm{~h}, 25^{\circ} \mathrm{C} \pm 0.3$ (night) and $70 \%$ relative humidity. Growth promoting or inhibiting potential of the culture filtrate of fungal isolates was screened on $O$. sativa seedlings because of their quick and easy reply to growth promoting phytohormones, like indole acetic acid (IAA) and gibberellins (GAs). The best growth promoting endophytes were inoculated to oil producing G. max and H. annuus crops, exposed to heat stress. G. $\max$ (Swat 84) and H. annuus (ICI Hyson 33 Australia) varieties were grown in autoclaved sand for two weeks in growth chambers. The conditions of one of the growth chambers (control experiment) was set at $28^{\circ} \mathrm{C} \pm 0.3,14 \mathrm{~h}$ (day), and $25^{\circ} \mathrm{C} \pm 0.3,10 \mathrm{~h}$ (night). Whereas, the conditions of the other growth chamber set for heat stress experiment was $14 \mathrm{~h}, 40^{\circ} \mathrm{C} \pm 0.3$ (day), $10 \mathrm{~h}, 35^{\circ} \mathrm{C} \pm 0.3$ (night). The relative humidity in both cases was kept at $70 \%$. All experiments were performed in triplicates. 


\section{Isolation of Fungal Endophytes}

Methodology of Khan, et al. [37] was applied for the isolation of fungal endophytes from Dryopteris blanfordii. A wild medicinal plant Dryopteris, was collected from dry rocky sun-side mountain of District Swat, Tehsil Kabal (DD COORDINATES: 34.7833302 72.2833322; DMS COORDINATES: 3446'59.99" N 72¹6'60.00" E; GEOHASH COORDINATES: tw5muu55edxn8; UTM COORDINATES: 43S 251415.10226142 3852379.1095829), Khyber Pakhtunkhwa, Pakistan in the month of July. The plants were carried to plant microbes' interaction (PMI) laboratory. Dryopteris was selected for the isolation of endophytes because many of the medicinal plant species, we have explored previously served as a pool of potential endophytes. Initially fungal isolates were grown in Hagem media, which was then purified using a PDA (potato dextrose agar) media. For the collection of secondary metabolites and biomass, the purified isolates were inoculated to Czapek media. The Czapek media were incubated for 7 days in a shaking incubator operated at $120 \mathrm{rpm}$.

\section{Initial Screening of Isolated Fungi on $O$. sativa Seedlings}

Initially, the isolated fungal strains were screened on $O$. sativa seedlings for their growth promoting potential at two leaves phase. Culture filtrate $(100 \mu \mathrm{l}) \mathrm{f}$ the fungal strains was applied to the tip of the $O$. sativa seedlings, grown in $0.8 \%$ water-agar medium. The plants were transferred to the growth chambers operated under conditions as described earlier and incubated for one week. Growth attributes, including total chlorophyll content, root and shoot length, fresh and dry weight of root and shoot, were measured and compared with distilled water and Czapek media as control [38].

\section{Molecular Identification of Fungal Isolate}

Identification of fungal isolate was carried out using molecular tools by the well described procedure of Khan et al. [39, 40]. Amplification of 18S rDNA was performed with ITS1 (5'-TCC GTA GGT GAA CCT GCG G-3') forward and ITS4 (5'-TCC TCC GCT TAT TGA TAT GC-3') reverse primers [41]. Approximation of sequence homology was carried out using BLASTn1 software for the attained sequence. For phylogenetic analysis, MEGA 7 software was used and trees were constructed with Neighbor Joining.

\section{Inoculation of $P$. glabrum to G. $\max$ and H. annuus}

Biomass of $P$. glabrum was applied to the pots containing autoclaved sand and seeds of G. $\max$ and H. annuus (6 seeds/pot). The pots were then transferred to the growth chamber operated under condition as described earlier. Minerals were applied in the form of Hoagland solution. Growth attributes of endophyteinoculated and non-inocu,ated $G$. $\max$ and $H$. annuus seedlings were noted and compared after 2 weeks of fungal inoculation [42].

\section{Determination of Antioxidants}

Fresh leaves (10 gram) of G. max or H. annuus were soaked in Sodium-phosphate buffer $(50 \mathrm{~mm}, \mathrm{pH}$ 7) containing $1 \%$ polyvinyl-pyrolidine $(\mathrm{w} / \mathrm{v})$. The mixture was spun at $4^{\circ} \mathrm{C}$ and $15,000 \mathrm{rpm}$ for twenty minutes. Supernatant was used to analyze the enzymatic activity. Catalase (EC 1.11.1.6) activity was determined using Luck [43] procedure with some modifications. Extinction co-efficient $\left(36 \times 10^{3} \mathrm{mM}^{-1} \mathrm{~cm}^{-1}\right)$ was applied to measure CAT activity and was shown as $\mathrm{EU} \mathrm{mg}^{-1}$ protein. Kar and Mishra [44] method was applied for POD, EC 1.11.1.7) activity. The mixture contained $\mathrm{H}_{2} \mathrm{O}_{2}$ $(50 \mu \mathrm{M}), \mathrm{H}_{3} \mathrm{PO}_{4}$ buffer $(125 \mu \mathrm{M} \mathrm{pH} 6.8)$, pyrogallol $(50 \mu \mathrm{M})$ and $20 \mathrm{X}$ diluted enzyme extract $(1 \mathrm{ml})$ in a $5 \mathrm{ml}$ total volume. Quantity of the developed purpurogallin was monitored at $420 \mathrm{~nm}$. POD concentration was calculated as $\mathrm{EU} \mathrm{mg}^{-1}$ protein. Beyer $\mathrm{Jr}$ and Fridovich [45] protocol was adopted for the investigation of SOD (EC 1.15.1.1) activity. SOD activity was monitored by noting a decrease in the absorbance of nitro-blue tetrazolium (NBT). SOD concentration was determined as EU mg ${ }^{-1}$ protein. Carlberg and Mannervik [46] method was applied for the activity of GR (GR, EC 1.6.4.2). GR was measured by the reduction in OD at $340 \mathrm{~nm}$ for two minutes. GR concentration was measured by applying an extinction co-efficient of $0.12 \mathrm{mM}$ NADPH, which was $6.2 \mathrm{mM}^{-1} \mathrm{~cm}^{-1}$, and was shown as EU $\mathrm{mg}^{-1}$ protein.

\section{Determination of ABA}

ABA concentration was determined in the leaves of G. max and H. annuus using optimized protocol of Yoon, et al. [18]. Fresh leaves $(0.5 \mathrm{~g})$ of G. $\max$ and $H$. annuиs were crushed using liquid $\mathrm{N}_{2}$ in a pestle and mortar. Glacial acetic acid $(28.5 \mathrm{ml})$ and isopropanol $(1.5 \mathrm{ml})$ were added to the sample. The mixture was then filtered and dehydrated through rotary evaporator. Diazo-methane was added to this mixture and examined via GC-MS SIM $(6890 \mathrm{~N}$ network GC system furnished with 5973 network mass-selective-detector, Agilent Technologies, Palo Alto, CA, USA). The Lab-Base (Thermo Quset, Manchester, UK) data system software was used to detect retorts to ions with $\mathrm{m} / \mathrm{z}$ values of 162 and 190 for Me-ABA and 166 and 194 for Me-[2H6]ABA. ABA ([2H6]-ABA) (Sigma Aldrich) was used as an internal standard.

\section{Determination of Phenolics and Proline}

Total proline contents were analyzed via methodology of Bates, et al. [47]. Various concentrations 
of proline (Sigma Aldrich; 2, 4, 6, 8, and $10 \mu \mathrm{g} / \mathrm{ml}$ ) were used to plot a standard curve. Optical density was noted at $520 \mathrm{~nm}$.

Cai, et al. [48] methodology of Folin-Ciocalteu colorimetric was followed to examine phenolics in $G$. $\max$ and $H$. annuus. Sample $(0.2 \mathrm{ml})$ and $0.5 \mathrm{~N}$ Folin-Ciocalteu reagent were mixed and kept for $4 \mathrm{~min}$ at $25^{\circ} \mathrm{C}$. Sodium carbonate $(75 \mathrm{~g} / \mathrm{l})$ was used for the neutralization of mixture and the mixture was heated at $100^{\circ} \mathrm{C}$ for 1 minute. This mixture was then kept in the dark for 2 hours. Optical density was taken at $650 \mathrm{~nm}$. Various concentrations of gallic acid were prepared to construct a standard curve $(100,200,300,500$ and 600, 700 and $900 \mathrm{mg} / \mathrm{ml}$ ).

\section{Determination of Total Lipids, Proteins and Sugars}

Proteins were determined in $H$. annuus and $G$. max seedlings using methodology of Lowry, et al. [49]. Homogenate of filtered leaf sample $(0.1 \mathrm{ml})$ was mixed with $0.1 \mathrm{ml}$ of $2 \mathrm{M} \mathrm{NaOH}$. The mixture was heated at $100^{\circ} \mathrm{C}$ to hydrolyse. The resulted hydrolysate was cooled and mixed with $1 \mathrm{ml}$ of complex-forming solution [complex-forming solution $=2 \%(\mathrm{w} / \mathrm{v}) \mathrm{Na}_{2} \mathrm{CO}_{3}$ in distilled $\mathrm{H}_{2} \mathrm{O}, 1 \%(\mathrm{w} / \mathrm{v}) \mathrm{CuSO}_{4} .5 \mathrm{H}_{2} \mathrm{O}$ in distilled $\mathrm{H}_{2} \mathrm{O}, 2 \%(\mathrm{w} / \mathrm{v})$ sodium potassium tartrate in distilled $\mathrm{H}_{2} \mathrm{O}$ ] and let the mixture stand for 10 minutes at room temperature. About, $1 \mathrm{ml}$ of Folin reagent was added and the mixture was vortexed. The mixture was allowed to stand for 30 minutes at room temperature. The absorbance was finally read at $650 \mathrm{~nm}$ using spectrophotometer. Different concentrations of bovine serum albumin (BSA) (Sigma Aldrich; 20, 40, 60, 80 , and $100 \mu \mathrm{g} / \mathrm{ml}$ ) was applied to draw a standard curve. Van Handel [50] methodology was followed for the analysis of total lipids. Crushed leaf sample was centrifuged and about $1 \mathrm{ml}$ of the supernatant was taken and transferred to the reaction tube containing $1 \mathrm{ml}$ chloroform/methanol $(1: 2 \mathrm{v} / \mathrm{v})$ solution. The mixture was heated in a water bath at $90^{\circ} \mathrm{C}$ until complete evaporation. Concentrated sulfuric acid
( $2 \mathrm{ml}$ ) was added to the precipitate formed and mixed with the help of vortex for 2 minutes and then heated on a water bath at $90^{\circ} \mathrm{C}$. The mixture was cooled and added $5 \mathrm{ml}$ vanillin-phosphoric acid reagent. The tube containing mixture was allowed to stand for 30 minutes at room temperature for colour development. Finally the tube was mixed and the absorbance was measured at $525 \mathrm{~nm}$. Various concentrations of pure canola oil $(10,40,70,100,130$, and $160 \mu \mathrm{g} / \mathrm{ml})$ was used to draw a standard curve. Mohammadkhani and Heidari [41] protocol was applied to determine soluble sugar in $H$. annuus and G. max leaves. Homogenate of filtered leaf sample $(1 \mathrm{ml})$ was mixed with $10 \mu \mathrm{l}$ of $5 \%$ phenol and $1 \mathrm{ml}$ of $98 \%$ sulfuric acid. The mixture was vortexed and allowed to stand for $1 \mathrm{~h}$. The absorbance was finally measured at $485 \mathrm{~nm}$ by using a spectrophotometer. Different concentrations of glucose (Sigma Aldrich; 20, $40,60,80$, and $100 \mu \mathrm{g} / \mathrm{ml}$ ) were taken to plot a standard curve.

\section{Statistical Analysis}

Experiments were accomplished in triplicates. ANOVA was applied to analyze the data. Mean values were equated by DMRT (Duncan Multiple Range Test) at $p<0.05$, via SPSS-20 (SPSS Inch., Chicago, IL, USA).

\section{Results and Discussion}

\section{Isolation Fungal Endophytes and Their Plant Growth Promoting Activity}

Nine different fungal isolates were collected from Dryopteris blanfordii. The growth promotion or inhibition potential of the endophytes was screened on $O$. sativa plantlets. The $P$. glabrum-treated $O$. sativa seedlings had more chlorophyll content (7\%), shoot $(37 \%)$ and root length (5\%). Similarly, higher weights were recorded for the fresh (36\%) and dry shoot (70\%), and fresh $(9 \%)$ and dry roots $(5 \%)$ in comparison to the Czapek-treated control seedlings (Table 1).

Table 1. Effect of P. glabrum filtrate on the growth of $O$. sativa seedlings.

\begin{tabular}{|c|c|c|c|}
\hline Growth attributes & Control (DW) & Control (Czk) & P. glabrum \\
\hline Shoot Length (cm) & $10.4 \pm 0.7^{\mathrm{a}}$ & $10.6 \pm 1.4^{\mathrm{a}}$ & $6 \pm 1.0^{\mathrm{a}}$ \\
\hline Root Length (cm) & $4.9 \pm 1.4^{\mathrm{a}}$ & $6.3 \pm 0.5^{\mathrm{a}}$ & $0.043 \pm 0.02^{\mathrm{b}}$ \\
\hline Fresh Weight Shoot (g) & $0.03 \pm .05^{\mathrm{a}}$ & $0.0317 \pm 0.05^{\mathrm{a}}$ & $0.1037 \pm 0.08^{\mathrm{b}}$ \\
\hline Fresh Weight Root (g) & $0.08 \pm 0.01^{\mathrm{a}}$ & $0.095 \pm 0.01^{\mathrm{a}}$ & $0.0073 \pm 0.0005^{\mathrm{b}}$ \\
\hline Dry Weight Shoot (g) & $0.0047 \pm 0.0005^{\mathrm{a}}$ & $0.0043 \pm 0.0005^{\mathrm{a}}$ & $0.016 \pm 0.001^{\mathrm{a}}$ \\
\hline Dry Weight Root (g) & $0.014 \pm 0.001^{\mathrm{a}}$ & $0.015 \pm 0.002^{\mathrm{a}}$ & $22.9 \pm 0.6^{\mathrm{b}}$ \\
\hline
\end{tabular}

Czk $=$ Czapek medium, DW $=$ Distilled water. Data are means of 3 replicates with standard error. Different letters are significantly different $(\mathrm{p}<0.05)$ as estimated by Duncan's Multiple Range Test (DMRT). 
DryR-30 isolate was the best growth promoter of $O$. sativa seedlings, which was selected for further analysis.

\section{Identification of Fungal Isolate DryR-30}

Internal Transcribed Spacer (ITS) region of the nucleotide sequence of DryR-30 isolate was equated with allied strains through the BLAST search program (Basic Local Alignment Search Tool, 2012). 18S rDNA sequence revealed maximum resemblance (54\%) with $P$. glabrum. The phylogenetic harmony tree was prepared from 1 cloned and 8 references via NJ (Neighbor Joining) technique using MEGA-7.0 software (Fig. 1). Results of sequence homology and phylogenetic examination proposed DryR-30 as P. glabrum.

\section{Growth Attributes of G. max and H. annuus Allied to P. glabrum}

Plant growth characteristics, such as total chlorophyll content, root-shoot length, and fresh and dry weight of root and shoot of experimental plants $(P$. glabrum-co-cultured) were measured and compared with control plants. All the plants were grown for two weeks, at $25^{\circ} \mathrm{C}$ and $40^{\circ} \mathrm{C}$. A significant increase in all growth attributes was found in $G$. $\max$ and $H$. annuus plantlets allied with $P$. glabrum as compared to control plantlets. Endophyte-associated $G$. max has enhanced chlorophyll (4\%), shoot length (34.6\%), root length $(40 \%)$, shoot $(28.5 \%)$ and root fresh weights $(6 \%)$, and shoot $(2 \%)$ and root dry weights $(24.5 \%)$, when exposed to thermal stress (Table 2). Similarly, the increase was also recorded in the chlorophyll content $(3 \%)$, shoot $(6 \%)$ and root length $(20 \%)$, fresh shoot (18\%) and fresh root weight (53\%), dry shoot $35 \%$ ) and dry root weight (33\%) of P. glabrum-inoculated H. annuus at heat stress as compared to control plants (Table 3). We observed a high content of chlorophyll in P. glabrum-inoculated $G$. max and $H$. annuus as compared to control seedlings. which might be due to enhancement in the uptake of

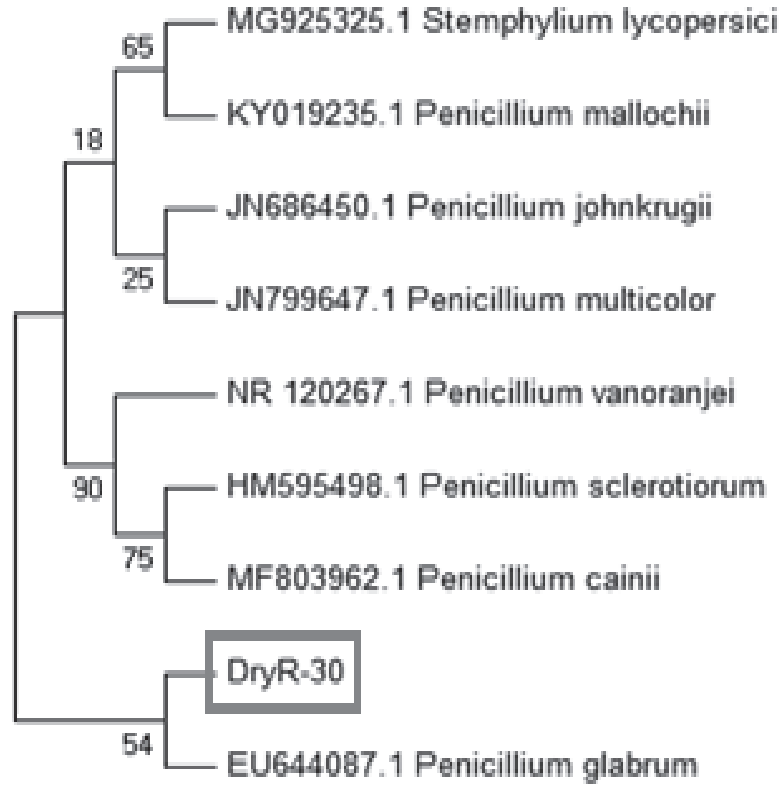

Fig. 1. Phylogenetic consensus tree construction (using 9 taxa, 8 reference and 1 clone) for the identification of fungal isolate DryR-30 using neighbor joining (NJ) method. 54\% bootstrap value confirmed isolate DRYR-30 as Penicillium glabrum.

Mg element by $P$. glabrum. In a similar experiment a high rate of photosynthesis was noted in Capsicum annuum colonized by an endophytic fungi Penicillium resedanum [51] and Chaetomium globosum [52] under drought stress.

\section{Intercession of Physiological Characteristics}

Higher concentration of flavonoids and phenolics, while reduced levels of proline contents were recorded in $G$. $\max$ and $H$. annuus allied with P. glabrum under heat stress as compared to control plants (Fig. 2). The maximum increase $(15.7 \%)$ in phenolic contents was noted in the seedlings of $H$. annuus, whereas the fungal strain was less responsive in G. $\max (5.6 \%)$ seedlings

Table 2. Effect of P. glabrum on the growth features of G. max.

\begin{tabular}{|c|c|c|c|c|}
\hline \multirow{2}{*}{$\begin{array}{c}\text { Growth attributes/ } \\
\text { temperature stress }\end{array}$} & \multicolumn{2}{|c|}{$25^{\circ} \mathrm{C}$} & \multicolumn{2}{c|}{$40^{\circ} \mathrm{C}$} \\
\cline { 2 - 5 } & Control & P. glabrum & Control & P. glabrum \\
\hline Shoot Length (cm) & $38.7 \pm 1.7^{\mathrm{b}}$ & $45.7 \pm 2.1^{\mathrm{c}}$ & $26 \pm 0.9^{\mathrm{a}}$ & $35 \pm 1.1^{\mathrm{b}}$ \\
\hline Root Length (cm) & $16 \pm 3.1^{\mathrm{a}}$ & $24 \pm 1.6^{\mathrm{b}}$ & $10 \pm .5^{\mathrm{a}}$ & $14 \pm 1.8^{\mathrm{a}}$ \\
\hline Fresh Weight Shoot (g) & $1.14 \pm .02^{\mathrm{ab}}$ & $1.42 \pm 0.2^{\mathrm{b}}$ & $0.82 \pm 0.3^{\mathrm{a}}$ & $1.06 \pm .02^{\mathrm{a}}$ \\
\hline Fresh Weight Root (g) & $0.18 \pm 0.01^{\mathrm{ab}}$ & $0.32 \pm 0.08^{\mathrm{b}}$ & $0.13 \pm 0.1^{\mathrm{a}}$ & $0.12 \pm 0.03^{\mathrm{ab}}$ \\
\hline Dry Weight Shoot (g) & $0.13 \pm 0.01^{\mathrm{c}}$ & $0.12 \pm 0.09^{\mathrm{c}}$ & $0.07 \pm 0.003^{\mathrm{a}}$ & $0.09 \pm 0.001^{\mathrm{b}}$ \\
\hline Dry Weight Root (g) & $0.065 \pm 0.005^{\mathrm{b}}$ & $0.075 \pm 0.002^{\mathrm{c}}$ & $0.010 \pm 0.001^{\mathrm{a}}$ & $0.013 \pm 0.003^{\mathrm{a}}$ \\
\hline Total Chlorophyll (SPAD) & $29 \pm 1.9^{\mathrm{a}}$ & $43 \pm 1.1^{\mathrm{b}}$ & $28.9 \pm 0.5^{\mathrm{a}}$ & $30 \pm 0.2^{\mathrm{a}}$ \\
\hline
\end{tabular}

Effect of P. glabrum on G. max seedlings, isolated from D. blanfordii. Data are means of 3 replicates with standard error. Different letters are significantly different $(\mathrm{p}<0.05)$ as estimated by Duncan's Multiple Range Test (DMRT). 
Table 3. Effect of P. glabrum on the growth features of H. annuus.

\begin{tabular}{|c|c|c|c|c|}
\hline \multirow{2}{*}{$\begin{array}{c}\text { Growth attributes/ } \\
\text { temperature stress }\end{array}$} & \multicolumn{2}{|c|}{$25^{\circ} \mathrm{C}$} & \multicolumn{2}{c|}{$40^{\circ} \mathrm{C}$} \\
\cline { 2 - 5 } & Control & P. glabrum & Control & Plabrum \\
\hline Total Chlorophyll (SPAD) & $39 \pm 1.2^{\mathrm{a}}$ & $42.6 \pm 2.5^{\mathrm{a}}$ & $37.4 \pm 0.6^{\mathrm{a}}$ & $38.4 \pm 1.9^{\mathrm{a}}$ \\
\hline Shoot Length (cm) & $24.5 \pm 0.8^{\mathrm{b}}$ & $28.9 \pm 0.8^{\mathrm{c}}$ & $20 \pm 0.4^{\mathrm{a}}$ & $23 \pm 0.8^{\mathrm{b}}$ \\
\hline Root Length (cm) & $9.0 \pm 0.5^{\mathrm{b}}$ & $11.9 \pm 0.5^{\mathrm{c}}$ & $5.0 \pm 0.2^{\mathrm{a}}$ & $6.0 \pm 0.5^{\mathrm{a}}$ \\
\hline Fresh Weight Shoot (g) & $1.22 \pm 0.09^{\mathrm{ab}}$ & $1.421 \pm 0.05^{\mathrm{b}}$ & $0.928 \pm 0.2^{\mathrm{a}}$ & $1.095 \pm 0.04^{\mathrm{ab}}$ \\
\hline Fresh Weight Root (g) & $0.131 \pm 0.02^{\mathrm{ab}}$ & $0.188 \pm 0.04^{\mathrm{b}}$ & $0.099 \pm 0.006^{\mathrm{a}}$ & $0.152 \pm 0.06^{\mathrm{ab}}$ \\
\hline Dry Weight Shoot (g) & $0.088 \pm 0.003^{\mathrm{b}}$ & $0.147 \pm 0.001^{\mathrm{c}}$ & $0.063 \pm 0.001^{\mathrm{a}}$ & $0.085 \pm 0.009^{\mathrm{b}}$ \\
\hline Dry Weight Root (g) & $0.024 \pm 0.001^{\mathrm{a}}$ & $0.103 \pm 0.006^{\mathrm{c}}$ & $0.0345 \pm 0.004^{\mathrm{a}}$ & $0.046 \pm 0.002^{\mathrm{b}}$ \\
\hline
\end{tabular}

Effect of P. glabrum on H. annuus seedlings, isolated from D. blanfordii. Data are means of 3 replicates with standard error. Data are means of 3 replicates with standard error. Different letters are significantly different $(\mathrm{p}<0.05)$ as estimated by Duncan's Multiple Range Test (DMRT).

in terms of rise in phenolics concentrations as equated to fungal-free seedlings. In contrast proline content was significantly reduced $(19.7 \%)$ in the seedlings of G. max as compared to H. annuus (16.8\%). Among the defensive compounds accumulated in higher plants, phenolics are known to have vital role against biotic and abiotic stresses [6]. Detection of high phenolic contents in endophyte-allied G. max and H. annuus plants under
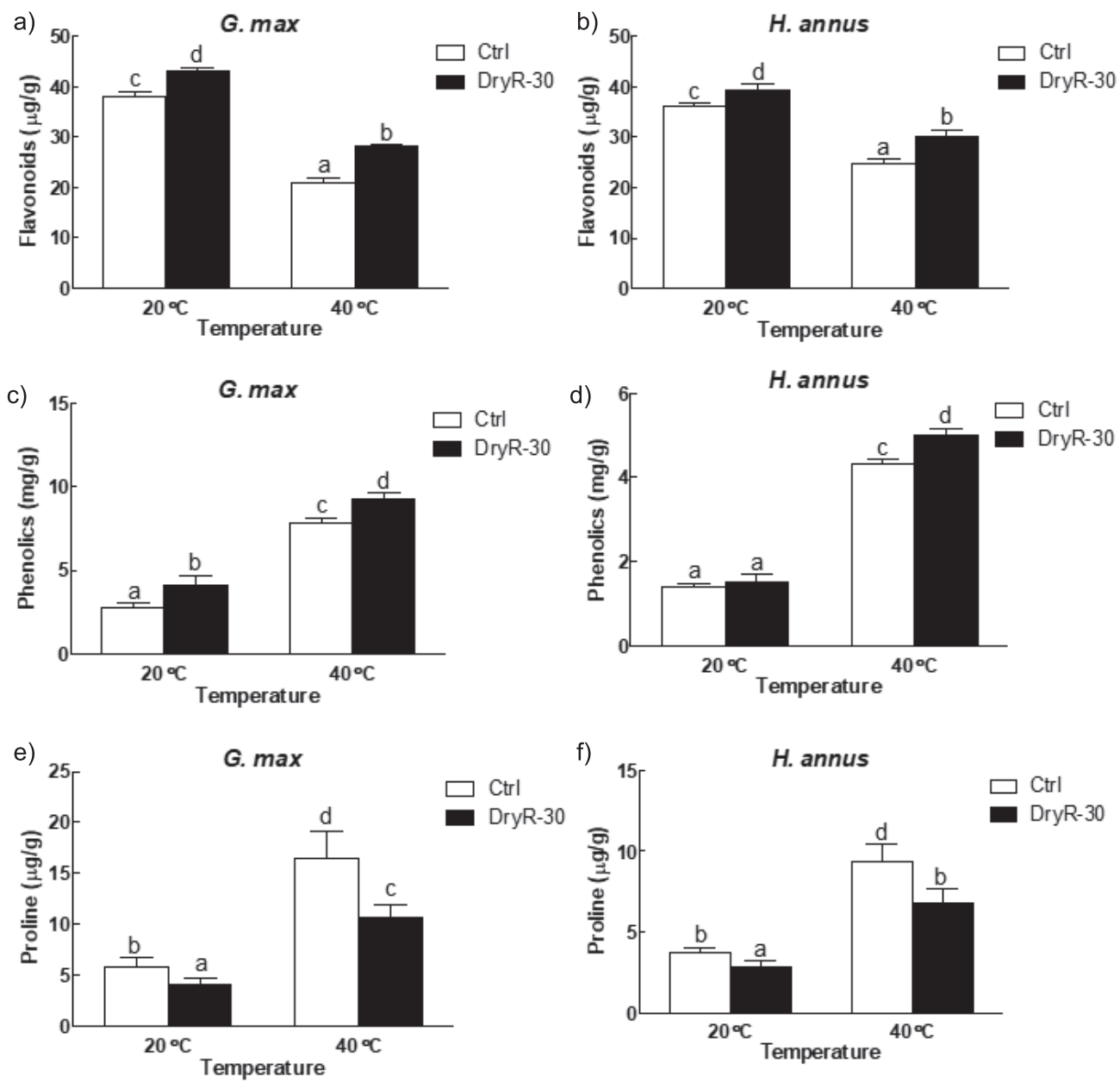

Fig. 2. Flavonids a), phenolics b) and proline c) in G. max and H. annuus inoculated with and without P. glabrum. Data are means of 3 replicates with standard error. Different letters are significantly different $(\mathrm{p}<0.05)$ as estimated by Duncan's Multiple Range Test (DMRT). 
thermal stress helped in mitigation of stress in plants [6]. Our results are similar to the work of Abd_Allah, et al. [53], who suggested that endophytes enhance phenolics content of their host plant under abiotic stress. Proline is known to function as organic osmolyte that accrue in various plants in response to different environmental stresses, including high temperature. A rise in proline was also noted in P. glabrum associated G. $\max$ and $H$. annuus. Such rise in proline content has an encouraging affect on plant endogenous enzymes, membrane integrity, free radicals scavenging, cellular redox potential and osmotic modification in plants during stress [54]. Moreover, proline has a role in relieving cytoplasmic acidosis, protein compatible hydrotrope and keeping suitable ratio of NADP+/NADPH [55].

A decline was noted in the concentration of ABA, in the leaves of endophyte-inoculated G. $\max$ and $H$. annuus seedlings at $25^{\circ} \mathrm{C}$ and $40^{\circ} \mathrm{C}$. G. max seedlings co-cultured with $P$. glabrum has $1 \%$ lesser ABA as equated to control seedlings at $25^{\circ} \mathrm{C}$, while at $40^{\circ} \mathrm{C}$ endophyte-inoculated $G$. $\max$ had $47 \%$ lesser ABA. Likewise, $P$. glabrum-inoculated $H$. annuus has $2 \%$ lesser $\mathrm{ABA}$ content at $25^{\circ} \mathrm{C}$, while $30 \%$ lesser $\mathrm{ABA}$ at $40^{\circ} \mathrm{C}$ as compared to the endophyte-free plants (Fig. 3 a-b). High level of $\mathrm{H}_{2} \mathrm{O}_{2}$ and lipid peroxidation were recorded in endophyte-free $G$. max and $H$. annuus seedlings, subjected to heat stress (i.e. $40^{\circ} \mathrm{C}$ ). Elevation in $\mathrm{H}_{2} \mathrm{O}_{2}$ content is known to have a negative impact on membrane integrity. Under normal temperature $\left(25^{\circ} \mathrm{C}\right)$, a reduced $\mathrm{H}_{2} \mathrm{O}_{2}$ levels were found in $P$. glabrum-aligned G. $\max (41 \%)$ and $H$. annuus (48\%), respectively. While, at thermal stress $\left(40^{\circ} \mathrm{C}\right)$ this decrease was $65 \%$ and $31 \%$, respectively (Fig. $3 \mathrm{c}, \mathrm{d}$ ). Quantification of lipids peroxidation was calculated in relation to MDA synthesis. A significant decrease was found in the amount of MDA in P. glabrum-aligned $G$. $\max$ and $H$. annuus. At $25^{\circ} \mathrm{C}$ the decrease was $40 \%$ and $43 \%$ in the G. $\max$ and $H$. annuus seedlings, respectively, while at $40^{\circ} \mathrm{C}$ the decrease was more in $H$. annuus (37\%) than in G. $\max (77 \%)$ seedlings (Fig. 3 e-f). Abscisic acid accumulates in higher plants exposed to various environmental stresses, including high temperature. Elevated content of ABA was observed in a similar study in $O$. sativa under thermal stress [56]. Thermal stress causes up-regulation of ABA biosynthesis genes, while down-regulates those genes a)

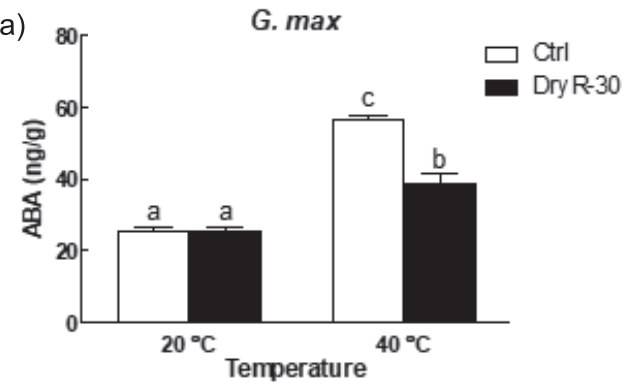

c)

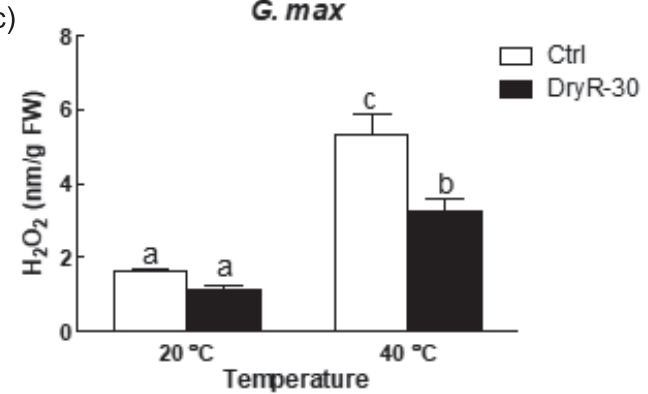

b)

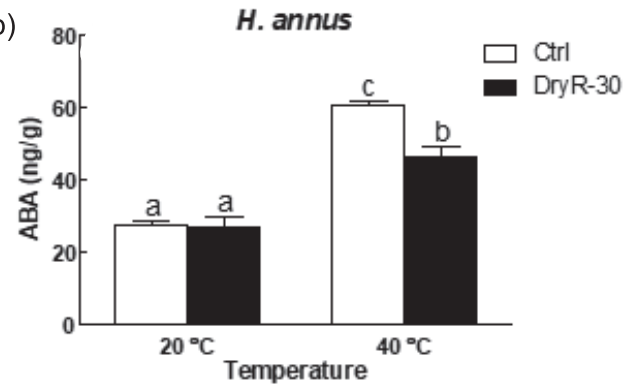

d)

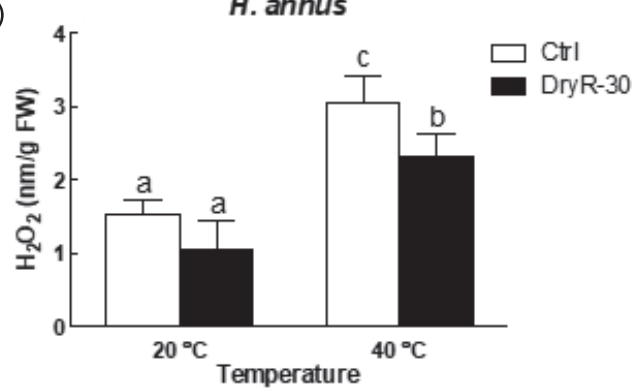

f)

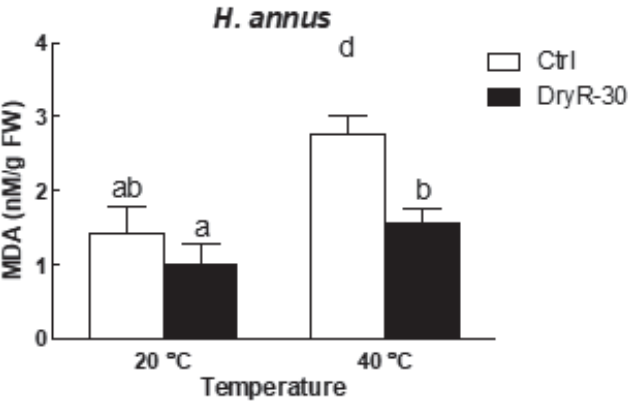

Fig. 3. ABA a) Hydrogen peroxide $\left(\mathrm{H}_{2} \mathrm{O}_{2}\right)$ b) and Lipid peroxidation (MDA) c) in $G$. max and $H$. annuus inoculated with and without $P$. glabrum. Data are means of 3 replicates with standard error. Different letters are significantly different ( $\mathrm{p}<0.05)$ as estimated by Duncan's Multiple Range Test (DMRT). 
Table 4. Effect of P. glabrum on the activity of antioxidant enzymes in G. max.

\begin{tabular}{|c|c|c|c|c|}
\hline \multirow{2}{*}{ Enzyme/temperature stress } & \multicolumn{2}{|c|}{$25^{\circ} \mathrm{C}$} & \multicolumn{2}{c|}{$40^{\circ} \mathrm{C}$} \\
\cline { 2 - 5 } & Control & P. glabrum & Control & P. glabrum \\
\hline AAO (Unit/g/30 sec.) & $1.56 \pm 0.08^{\mathrm{a}}$ & $1.78 \pm 0.03^{\mathrm{a}}$ & $1.80 \pm 0.12^{\mathrm{b}}$ & $2.09 \pm 0.12^{\mathrm{c}}$ \\
\hline CAT (Unit/g/30 sec.) & $0.42 \pm 0.03^{\mathrm{a}}$ & $0.60 \pm 0.02^{\mathrm{b}}$ & $0.93 \pm 0.04^{\mathrm{c}}$ & $1.14 \pm 0.08^{\mathrm{d}}$ \\
\hline POD (U/mg protein) & $1.16 \pm 0.08^{\mathrm{a}}$ & $1.39 \pm 0.18^{\mathrm{b}}$ & $4.61 \pm 0.57^{\mathrm{c}}$ & $5.73 \pm 0.21^{\mathrm{d}}$ \\
\hline SOD (U/mg protein) & $20 \pm 1.89^{\mathrm{a}}$ & $23 \pm 0.70^{\mathrm{a}}$ & $43 \pm 1.45^{\mathrm{b}}$ & $57 \pm 1.04^{\mathrm{c}}$ \\
\hline GR (U/mg protein) & $1.37 \pm 0.19^{\mathrm{a}}$ & $1.44 \pm 0.19^{\mathrm{a}}$ & $1.63 \pm 0.03^{\mathrm{b}}$ & $2.01 \pm 0.13^{\mathrm{c}}$ \\
\hline
\end{tabular}

Effect of $P$. glabrum on $H$. annuus seedlings, isolated from $D$. blanfordii. AAO = ascorbic acid oxidase; CAT = catalase;

$\mathrm{POD}=$ peroxidase, $\mathrm{SOD}=$ superoxide dismutase; $\mathrm{GR}=$ glutathione reductase. Data are means of 3 replicates with standard error.

Different letters are significantly different $(\mathrm{p}<0.05)$ as estimated by Duncan's Multiple Range Test (DMRT).

which are responsible for ABA catabolism [57]. In present work, elevated contents of ABA was noted in sunflower and soybean inoculated with P. glabrum subjected to high temperature stress as compared to non-inoculated seedlings. This reduction in ABA content in experimental plants might be due to downregulation of genes responsible for ABA synthesis or acceleration of ABA degradation. Low amount of ABA in fungal endophyte associated G. $\max$ and $H$. annuus confirmed the findings of Hamayun, et al. [21]. Low amount of ABA in endophyte-associated plants may be due to the participation of GAs, as exogenous application of GAs enhance stress tolerance in G. $\max$ escorted by reduced amount of ABA. Plants initiate some intricate biosynthetic responses, like antioxidant systems, adjustments in membrane lipids, osmotic potential, and synthesis of heat-shock-proteins, under heat stress [53]. In the present study, we detected that P. glabrum-associated G. $\max$ and $H$. annuus seedlings are more resistant to thermal stress than nonallied seedlings. It is known that plant's biochemical, physiological and transcriptional mechanisms are severely affected by thermal stress. Oxidative stress results in the accumulation of high concentration of MDA in control plants due to lipids peroxidation. In our study, both $G$. max and $H$. annuus control seedlings exposed to heat stress, have elevated levels of MDA as compared to P. glabrum-associated plants. The rise in MDA concentration is injurious to plants that cause membrane damaging, while endophytes are known to reduce the impacts of abiotic stresses by reducing the level of MDA in their host plants [5]. In one such type of work, $27.5 \%$ decrease in the levels of MDA was found in Chickpea plants inoculated with Bacillus subtilis BERA 71 facing $200 \mathrm{mM} \mathrm{NaCl}$ salt stress [58]. Our study confirmed the work of Abd_Allah, et al. [53] on chickpea that endophytes ameliorate abiotic stresses by reducing the levels of MDA and $\mathrm{H}_{2} \mathrm{O}_{2}$. As stated earlier that thermal stress boosts up $\mathrm{H}_{2} \mathrm{O}_{2}$ in plants, which might affect membrane structural integrity and directs lipids peroxidation, hence more MDA synthesis, which is noted in control $G$. max and $H$. annuus seedlings [5, 6, 14].

A considerable rise was seen in antioxidants activities, including AAO, CAT, POD, SOD and GR in endophyte-aligned $G$. $\max$ and $H$. annuus seedlings at $40^{\circ} \mathrm{C}$ as equated to non-aligned $P$. glabrum seedlings. $P$. glabrum-aligned $G$. max seedlings have enhanced concentrations of CAT (20\%), POD (49\%), AAO (13\%), SOD (24\%) and GR (28\%) (Table 4). Similarly, enhanced concentration of CAT (27\%) POD (28\%), AAO (13.6\%), SOD (21\%) and GR (40\%) was also

Table 5. Effect of P. glabrum on the activity of antioxidant enzymes in H. annuus.

\begin{tabular}{|c|c|c|c|c|}
\hline \multirow{2}{*}{ Enzyme/temperature stress } & \multicolumn{2}{|c|}{$25^{\circ} \mathrm{C}$} & \multicolumn{2}{c|}{$40^{\circ} \mathrm{C}$} \\
\cline { 2 - 5 } & Control & P. glabrum & Control & P. glabrum \\
\hline AAO (Unit/g/30 sec.) & $0.64 \pm 0.06^{\mathrm{a}}$ & $0.87 \pm 0.06^{\mathrm{b}}$ & $2.26 \pm 0.36^{\mathrm{c}}$ & $2.58 \pm 0.28^{\mathrm{c}}$ \\
\hline CAT (Unit/g/30 sec.) & $0.23 \pm 0.03^{\mathrm{a}}$ & $0.37 \pm 0.02^{\mathrm{b}}$ & $0.55 \pm 0.04^{\mathrm{c}}$ & $0.75 \pm 0.03^{\mathrm{d}}$ \\
\hline POD (U/mg protein) & $0.98 \pm 0.07^{\mathrm{a}}$ & $1.23 \pm 0.02^{\mathrm{b}}$ & $3.54 \pm 0.57^{\mathrm{c}}$ & $4.15 \pm 0.08^{\mathrm{d}}$ \\
\hline SOD (U/mg protein) & $14 \pm 0.91^{\mathrm{a}}$ & $20 \pm 0.98^{\mathrm{b}}$ & $27 \pm 1.13^{\mathrm{c}}$ & $36 \pm 1.78^{\mathrm{d}}$ \\
\hline GR (U/mg protein) & $0.60 \pm 0.06^{\mathrm{a}}$ & $0.57 \pm 0.12^{\mathrm{a}}$ & $1.95 \pm 0.15^{\mathrm{b}}$ & $2.56 \pm 0.07^{\mathrm{c}}$ \\
\hline
\end{tabular}

Effect of $P$. glabrum on $H$. annuus seedlings, isolated from $D$. blanfordii. AAO = ascorbic acid oxidase; CAT = catalase;

$\mathrm{POD}=$ peroxidase, $\mathrm{SOD}=$ superoxide dismutase; $\mathrm{GR}=$ glutathione reductase. Data are means of 3 replicates with standard error.

Different letters are significantly different $(\mathrm{p}<0.05)$ as estimated by Duncan's Multiple Range Test (DMRT). 
recorded in $P$. glabrum-aligned $H$. annuus as compared to endophyte-free seedlings (Table 5). The ameliorative role of $P$. glabrum for $G$. max and $H$. annuus against heat stress might be due to the up-regulation of nutrients uptake and antioxidant system, and decline of ROS [59]. The enzymatic antioxidant system of plants, include CAT, POD, SOD, AAO and GR. The up-regulation of these antioxidants protect plant's membrane from the hazardous effects of free radicals generated under various stresses [53]. SOD is an important antioxidant enzyme that functions as scavenging of $\mathrm{H}_{2} \mathrm{O}_{2}$ and superoxide radicals for the synthesis of hydroxyl (OH-) radicals and decline of Haber-Weiss reaction. It is also known that up-regulation of CAT, POD, SOD and GR reduced membrane dysfunction in chickpea. Stress toxicity is reduced by high content of POD that might be due to accelerating lignins biosynthesis and other protective compounds [60]. Enhanced activity of CAT boost up immunity against abiotic stress in Brassica juncea [61]. CAT function as eliminator of $\mathrm{H}_{2} \mathrm{O}_{2}$ to protect membranes and organelles damage because $\mathrm{H}_{2} \mathrm{O}_{2}$ is known as signaling molecule, which quickly diffuses through membrane [62]. AAO and GR are important compounds of ROS degrading pathway that comprises the ascorbate-glutathione cycle [56]. A sequence of oxidation-reduction reactions arises in the ascorbate-glutathione cycle leading to eliminate $\mathrm{H}_{2} \mathrm{O}_{2}$ in cytosol and chloroplasts to reduce the toxicity of oxidative-stress on plants under abiotic stress. Rise in the activity of AAO and GR in heat affected seedlings might be owing to the safeguarding of photosynthetic electron transport chain (PETC) by keeping balance of $\mathrm{NADP}+$ /NADPH ratio for unceasing stream of electrons to $\mathrm{O}_{2}$, leading in abridged superoxide radicals' creation [56].

Lipids, proteins and sugars of G. max and H. annuus were determined via spectrophotometer. Endophyteinoculated G. $\max$ has $56 \%$ and $H$. annuus has $75 \%$ more protein at $40{ }^{\circ} \mathrm{C}$, while at $25^{\circ} \mathrm{C}$ G. $\max$ had $44 \%$ and $H$. annuus had $39 \%$ more proteins as compared to the endophyte-free plants (Fig. 4a-b). At $40^{\circ} \mathrm{C}$, $P$. glabrum-aligned G. max had $32 \%$ and $H$. annuus had $54 \%$ more soluble sugars, while at $25^{\circ} \mathrm{C}$ G. $\max$ had $19 \%$ and $H$. annuus had $38 \%$ more soluble sugars as equated to P. glabrum-free seedlings (Fig. 4c-d). Moreover, an increase of $27 \%$ and $26 \%$ in the total lipid contents
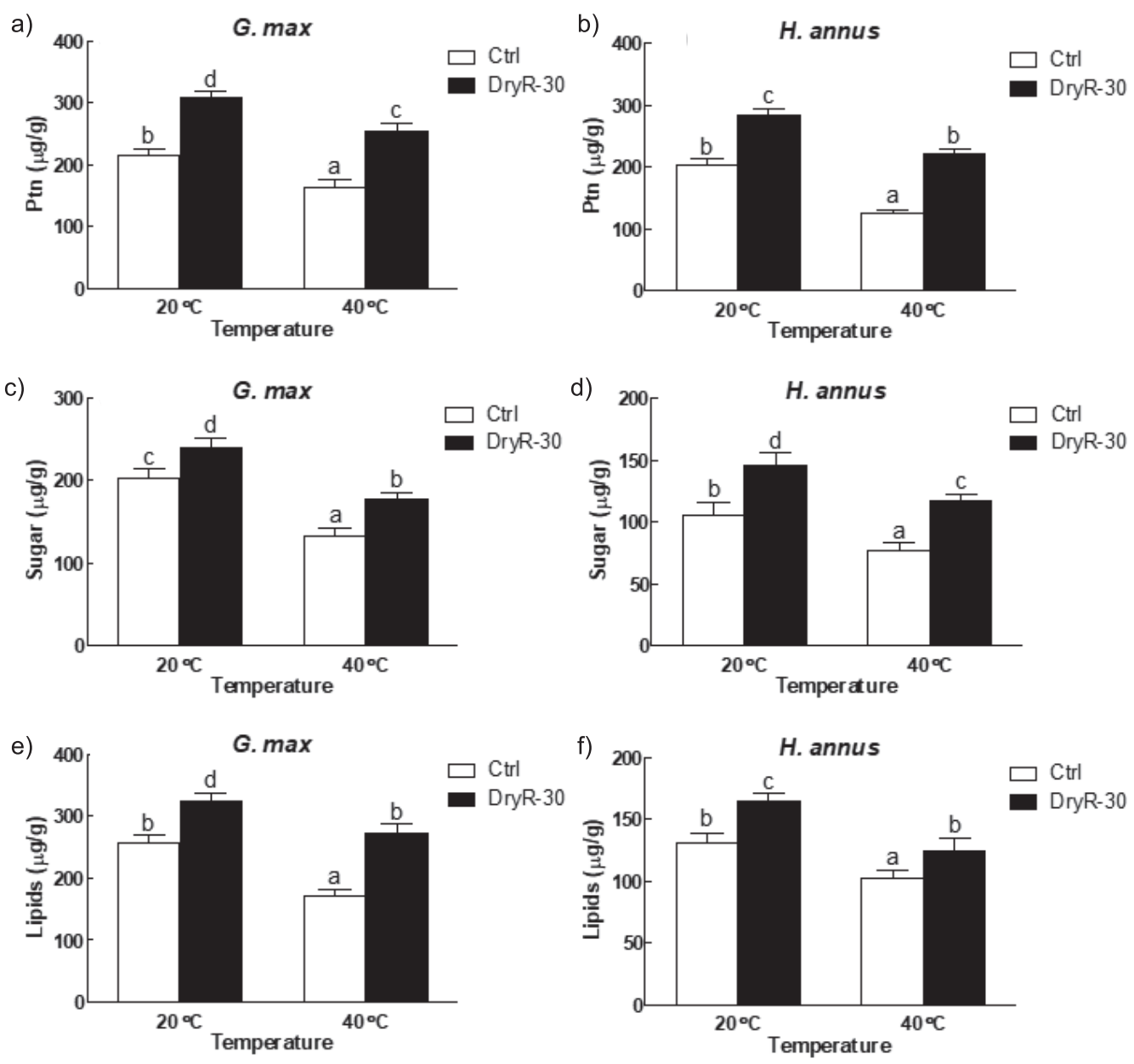

Fig. 4. Analysis of total proteins s), soluble sugars b) and lipids c) of G. max and H. annuus inoculated with P. glabrum. Data are means of 3 replicates with standard error. Different letters are significantly different $(\mathrm{p}<0.05)$ as estimated by Duncan's Multiple Range Test (DMRT). 
of P. glabrum-inoculated G. $\max$ and H. annuus were recorded at $25^{\circ} \mathrm{C}$ as compared to the non-inoculated plants (Fig. 4). At $40^{\circ} \mathrm{C}, P$. glabrum-associated $G$. $\max (60 \%)$ and $H$. annuus $(21 \%)$ had more lipids as compared to control seedlings (Fig. 4 e-f). Improvement in the total nutritional value (lipids, proteins and sugars) of $P$. glabrum-associated $G$. $\max$ and $H$. annuus was found under thermal stress, signifying the beneficial role of endophytic fungi for crops and hence their use as bio-fertilizers.

\section{Conclusion}

It is well known that thermal stress is one of the major restraints of food crops, including $G$. $\max$ and $H$. annuus. So, this work signifies thermo-tolerant potential of P. glabrum. P. glabrum not only enhanced growth in $G$. $\max$ and $H$. annuus, but also facilitated it to resist heat stress by boosting ROS scavenging antioxidant system of host plants. Furthermore, P. glabrum also tempered endogenous level of ABA in $G$. max and $H$. annuиs as well as boosted their nutritional value. The present study suggests the use of $P$. glabrum as heat stress alleviating bio-agent and bio-fertilizer in the future for sustainable agriculture.

\section{Acknowledgements}

This research was supported by the Basic Science Research Program through the National Research Foundation of Korea (NRF) funded by the Ministry of Education (2017R1D1A1B04035601).

\section{Conflict of Interest}

The authors declare no conflict of interest.

\section{References}

1. PORCEL R., AROCA R., RUIZ-LOZANO J.M. Salinity stress alleviation using arbuscular mycorrhizal fungi. A review. Agron. Sustain. Dev. 32 (1), 181, 2012.

2. FAHAD S., BAJWA A. A., NAZIR U., ANJUM S. A., FAROOQ A., ZOHAIB A., SADIA S., NASIM W., ADKINS S., SAUD S. Crop production under drought and heat stress: plant responses and management options. Front. Plant Sci. 8, 1147, 2017.

3. FAHAD S., HUSSAIN S., SAUD S., HASSAN S., CHAUHAN B.S., KHAN F., IHSAN M. Z., ULLAH A., WU C., BAJWA A.A. Responses of rapid viscoanalyzer profile and other rice grain qualities to exogenously applied plant growth regulators under high day and high night temperatures. PLoS One. 11 (7), e 0159590 , 2016.

4. FAHAD S., IHSAN M. Z., KHALIQ A., DAUR I., SAUD S., ALZAMANAN S., NASIM W., ABDULLAH M., KHAN I.A., WU C. Consequences of high temperature under changing climate optima for rice pollen characteristics-concepts and perspectives. Archives of Agronomy and Soil Science. 64 (11), 1473, 2018.

5. ISMAIL, HAMAYUN M., HUSSAIN A., AFZAL KHAN S., IQBAL A., LEE I.-J. Aspergillus flavus promoted the growth of soybean and sunflower seedlings at elevated temperature. BioMed Research International. 2019, 1, 2019.

6. ISMAIL, HAMAYUN M., HUSSAIN A., IQBAL A., KHAN S.A., LEE I.-J. Endophytic fungus Aspergillus japonicus mediates host plant growth under normal and heat stress conditions. BioMed Research International. 2018, 1, 2018.

7. ALI S., KHAN S.A., HAMAYUN M., IQBAL A., KHAN A.L., HUSSAIN A., SHAH M. Endophytic fungi from Caralluma acutangula can secrete plant growth promoting enzymes. Fresenius Environmental Bulletin. 28, 2688, 2019.

8. ISMAIL, ANWAR H., MEHMOOD A., QADIR M., HUSNA, AMJAD I., HAMAYUN M., KHAN N. Thermal stress alleviating potential of endophytic fungus Rhizopus Oryzae Inoculated To Sunflower (Helianthus annuus L.) and soybean (Glycine max L.). Pak. J. Bot. 52, 1, 2020.

9. JAMIL M., ALI A., GHAFOOR A., GUL A., AKBAR K.F., BASHIR H., IJAZ A., HUSSAIN R., MUNEEB A., NAVEED N.H. Yield reduction analysis of bread wheat under heat stress at two different environments in Pakistan. Fresenius Environmental Bulletin. 4602, 2017.

10. ABDELAAL A., OMARA I., HAFEZ M., SAMAR M., EL SABAGH A. Anatomical, biochemical and physiological changes in some Egyptian wheat cultivars inoculated with Puccinia graminis f. sp. tritici. Fresenius Environmental Bulletin. 27 (1), 296, 2018.

11. ISMAIL, ANWAR H., MEHMOOD A., QADIR M., HUSNA, IQBAL A., HAMAYUN M., KHAN N. Thermal stress alleviating potential of endophytic fungus Rhizopus oryzae inoculated to sunflower (Helianthus annuus L.) And soybean (Glycine max L.). Pakistan Journal of Botany. $\mathbf{5 2}, 1,2020$.

12. ISMAIL, HAMAYUN M., ANWAR H., SUMERA AFZAL K., AMJAD I., IN-JUNG L. An endophytic fungus Aspergillus violaceofuscus can be used as heat stress adaptive tool for Glycine $\max$ L. and Helianthus annuus L. Journal of Applied Botany and Food Quality. 93112,2020

13. ISMAIL, HAMAYUN M., HUSSAIN A., AFZAL KHAN S., IQBAL A., LEE I.-J. Aspergillus niger boosted heat stress tolerance in sunflower and soybean via regulating their metabolic and antioxidant system. Journal of Plant Interactions. 15, 223, 2020.

14. ISMAIL, MUHAMMAD H., ANWAR H., AMJAD I., SUMERA A.K., IN-JUNG L. Aspergillus niger boosted heat stress tolerance in sunflower and soybean via regulating their metabolic and antioxidant system. Journal of Plant Interactions. 15, 223, 2020.

15. ALQARAWI A.A., ABD ALLAH E., HASHEM A. Alleviation of salt-induced adverse impact via mycorrhizal fungi in Ephedra aphylla Forssk. J. Plant Interact. 9 (1), 802, 2014.

16. GHORBANPOUR M., HATAMI M., KHAVAZI K. Role of plant growth promoting rhizobacteria on antioxidant enzyme activities and tropane alkaloid production of Hyoscyamus niger under water deficit stress. Turk J Biol. 37 (3), 350, 2013.

17. ABD-ALLAH E.F., HASHEM A., ALQARAWI A.A., BAHKALI A.H., ALWHIBI M.S. Enhancing growth 
performance and systemic acquired resistance of medicinal plant Sesbania sesban (L.) Merr using arbuscular mycorrhizal fungi under salt stress. Saudi J. Biol. Sci. 22 (3), 274, 2015.

18. YOON J. Y., HAMAYUN M., LEE S.-K., LEE I.-J. Methyl jasmonate alleviated salinity stress in soybean. Journal of Crop Science and Biotechnology. 12 (2), 63-68, 2009.

19. KANG J., HWANG J.-U., LEE M., KIM Y.-Y., ASSMANN S. M., MARTINOIA E., LEE Y. PDR-type ABC transporter mediates cellular uptake of the phytohormone abscisic acid. Proc. Natl. Acad. Sci. 107 (5), 2355, 2010.

20. HAMAYUN M., HUSSAIN A., KHAN S.A., IRSHAD M., KHAN A.L., WAQAS M., SHAHZAD R., IQBAL A., ULLAH N., REHMAN G. Kinetin modulates physiohormonal attributes and isoflavone contents of Soybean grown under salinity stress. Front. Plant Sci. 6, 377, 2015.

21. HAMAYUN M., HUSSAIN A., KHAN S.A., KIM H.-Y., KHAN A.L., WAQAS M., IRSHAD M., IQBAL A., REHMAN G., JAN S. Gibberellins producing endophytic fungus Porostereum spadiceum AGH786 rescues growth of salt affected soybean. Frontiers in Microbiology. 8, 686, 2017.

22. KHAN M.A., HAMAYUN M., IQBAL A., KHAN S.A., HUSSAIN A., ASAF S., KHAN A. L., YUN B.-W., LEE I.-J. Gibberellin application ameliorates the adverse impact of short-term flooding on Glycine max L. Biochem. J. 475 (18), 2893, 2018.

23. BILAL L., ASAF S., HAMAYUN M., GUL H., IQBAL A., ULLAH I., LEE I.-J., HUSSAIN A. Plant growth promoting endophytic fungi Asprgillus fumigatus TS1 and Fusarium proliferatum BRL1 produce gibberellins and regulates plant endogenous hormones. Symbiosis. 76 (2), 117, 2018.

24. JAN F. G., HAMAYUN M., HUSSAIN A., JAN G., IQBAL A., KHAN A., LEE I.-J. An endophytic isolate of the fungus Yarrowia lipolytica produces metabolites that ameliorate the negative impact of salt stress on the physiology of maize. BMC Microbiology. 19 (1), 1, 2019.

25. GUL JAN F., HAMAYUN M., HUSSAIN A., IQBAL A., JAN G., KHAN S.A., KHAN H., LEE I.-J. A promising growth promoting Meyerozyma caribbica from Solanum xanthocarpum alleviated stress in maize plants. Bioscience Reports. 39, 1, 2019.

26. KUROMORI T., MIYAJI T., YABUUCHI H., SHIMIZU H., SUGIMOTO E., KAMIYA A., MORIYAMA Y., SHINOZAKI K. ABC transporter AtABCG25 is involved in abscisic acid transport and responses. Proc. Natl. Acad. Sci. 107 (5), 2361, 2010.

27. MIERZIAK J., KOSTYN K., KULMA A. Flavonoids as important molecules of plant interactions with the environment. Molecules. 19 (10), 16240, 2014.

28. IKRAM M., ALI N., JAN G., JAN F. G., RAHMAN I. U., IQBAL A., HAMAYUN M. IAA producing fungal endophyte Penicillium roqueforti Thom., enhances stress tolerance and nutrients uptake in wheat plants grown on heavy metal contaminated soils. PloS One. 13 (11), e0208150, 2018

29. MUHAMMAD I., NIAZ A., GUL J., AMJAD I., MUHAMMAD H., FARZANA G. J., ANWAR H., INJUNG L. Trichoderma reesei improved the nutrition status of wheat crop under salt stress. Journal of Plant Interactions. 14, 590, 2019.

30. MEHMOOD A., HUSSAIN A., IRSHAD M., HAMAYUN M., IQBAL A., KHAN N. In vitro production of IAA by endophytic fungus Aspergillus awamori and its growth promoting activities in Zea mays. Symbiosis. 77, 225, 2019.
31. MEHMOOD A., HUSSAIN A., IRSHAD M., HAMAYUN M., IQBAL A., RAHMAN H., TAWAB A., AHMAD A., AYAZ S. Cinnamic acid as an inhibitor of growth, flavonoids exudation and endophytic fungus colonization in maize root. Plant Physiol. Biochem. 135, 61, 2019.

32. KANG S.-M., HAMAYUN M., KHAN M. A., IQBAL A., LEE I.-J. Bacillus subtilis JW1 enhances plant growth and nutrient uptake of Chinese cabbage through gibberellins secretion. Journal of Applied Botany and Food Quality. 92, 172, 2019.

33. KHUSHDIL F., JAN F. G., JAN G., HAMAYUN M., IQBAL A., HUSSAIN A., BIBI N. Salt stress alleviation in Pennisetum glaucum through secondary metabolites modulation by Aspergillus terreus. Plant Physiology and Biochemistry. 144, 127, 2019.

34. QADIR M., HUSSAIN A., HAMAYUN M., SHAH M., IQBAL A., MURAD W. Phytohormones producing rhizobacterium alleviates chromium toxicity in Helianthus annuus L. by reducing chromate uptake and strengthening antioxidant system. Chemosphere. 127386, 2020.

35. ADNAN M., FAHAD S., ZAMIN M., SHAH S., MIAN I.A., DANISH S., ZAFAR-UL-HYE M., BATTAGLIA M.L., NAZ R.M.M., SAEED B. Coupling phosphatesolubilizing bacteria with phosphorus supplements improve maize phosphorus acquisition and growth under lime induced salinity stress. Plants. 9 (7), 900, 2020.

36. MUKHERJEE A., DAS D., MONDAL S. K., BISWAS R., DAS T.K., BOUJEDAINI N., KHUDA-BUKHSH A.R. Tolerance of arsenate-induced stress in Aspergillus niger, a possible candidate for bioremediation. Ecotoxicol. Environ. Saf. 73 (2), 172, 2010.

37. KHAN S.A., HAMAYUN M., YOON H., KIM H.-Y., SUH S.-J., HWANG S.-K., KIM J.-M., LEE I.-J., CHOO Y.-S., YOON U.-H. Plant growth promotion and Penicillium citrinum. BMC Microbiol. 8 (1), 231, 2008.

38. KHAN S. A., HAMAYUN M., KIM H.-Y., YOON H.J., SEO J.-C., CHOO Y.-S., LEE I.-J., RHEE I.-K., KIM J.-G. A new strain of Arthrinium phaeospermum isolated from Carex kobomugi Ohwi is capable of gibberellin production. Biotechnol. Lett. 31 (2), 283, 2009.

39. ELAD Y., PERTOT I. Climate change impacts on plant pathogens and plant diseases. J. Crop Improv. 28 (1), 99, 2014.

40. BORNMAN J.F., BARNES P.W., ROBINSON S.A., BALLARE C.L., FLINT S., CALDWELL M.M. Solar ultraviolet radiation and ozone depletion-driven climate change: effects on terrestrial ecosystems. Photochem. Photobiol. Sci. 14 (1), 88, 2015.

41. MOHAMMADKHANI N., HEIDARI R. Drought-induced accumulation of soluble sugars and proline in two maize varieties. World Appl. Sci. J. 3 (3), 448, 2008.

42. MISRA N., DWIVEDI U. Genotypic difference in salinity tolerance of green gram cultivars. Plant Sci. 166 (5), 1135, 2004.

43. LUCK H. Methods in Enzymatic Analysis II (ed.) Bergmeyer. (Publ.), Academic Press, New York: 1974.

44. KAR M., MISHRA D. Catalase, peroxidase, and polyphenoloxidase activities during rice leaf senescence. Plant Physiol. 57 (2), 315, 1976.

45. BEYER JR W.F., FRIDOVICH I. Assaying for superoxide dismutase activity: some large consequences of minor changes in conditions. Anal. Biochem. 161 (2), 559, 1987.

46. CARLBERG I., MANNERVIK B. [59] Glutathione reductase, Elsevier: 484, 1985. 
47. BATES L.S., WALDREN R.P., TEARE I. Rapid determination of free proline for water-stress studies. Plant and Soil. 39 (1), 205, 1973.

48. CAI Y., LUO Q., SUN M., CORKE H. Antioxidant activity and phenolic compounds of 112 traditional Chinese medicinal plants associated with anticancer. Life Sci. 74 (17), 2157, 2004.

49. LOWRY O.H., ROSEBROUGH N.J., FARR A.L., RANDALL R.J. Protein measurement with the Folin phenol reagent. J. Biol. Chem. 193, 265, 1951.

50. VAN HANDEL E. Rapid determination of total lipids in mosquitoes. J. Am. Mosq. Control Assoc. 1 (3), 302, 1985.

51. KHAN A.L., WAQAS M., LEE I.-J. Resilience of Penicillium resedanum LK6 and exogenous gibberellin in improving Capsicum annuum growth under abiotic stresses. J Plant Res. 128 (2), 259, 2015.

52. KHAN A.L., SHINWARI Z.K., KIM Y.-H., WAQAS M., HAMAYUN M., KAMRAN M., LEE I.-J. Role of endophyte Chaetomium globosum LK4 in growth of Capsicum annuum by producion of gibberellins and indole acetic acid. Pak. J. Bot. 44 (5), 1601, 2012.

53. ABD-ALLAH E.F., ALQARAWI A.A., HASHEM A., RADHAKRISHNAN R., AL-HUQAIL A.A., AL-OTIBI F.O.N., MALIK J.A., ALHARBI R.I., EGAMBERDIEVA D. Endophytic bacterium Bacillus subtilis (BERA 71) improves salt tolerance in chickpea plants by regulating the plant defense mechanisms. Journal of Pant Interactions. 13 (1), 37, 2018.

54. SHINOZAKI K., YAMAGUCHI-SHINOZAKI K. Gene networks involved in drought stress response and tolerance. J Exp Bot. 58 (2), 221, 2007.
55. HARE P., CRESS W. Metabolic implications of stressinduced proline accumulation in plants. Plant Growth Regul. 21 (2), 79, 1997.

56. RAGHAVENDRA A.S., GONUGUNTA V.K., CHRISTMANN A., GRILL E. ABA perception and signalling. Trends Plant Sci. 15 (7), 395, 2010.

57. TOH S., IMAMURA A., WATANABE A., NAKABAYASHI K., OKAMOTO M., JIKUMARU Y., HANADA A., ASO Y., ISHIYAMA K., TAMURA N. High temperature-induced abscisic acid biosynthesis and its role in the inhibition of gibberellin action in Arabidopsis seeds. Plant Physiol. 146 (3), 1368, 2008.

58. SONG Y., CHEN Q., CI D., SHAO X., ZHANG D. Effects of high temperature on photosynthesis and related gene expression in poplar. BMC Plant Biology. 14 (1), 111, 2014.

59. CHANG J., WANG Y., SHAO L., LABERGE R.-M., DEMARIA M., CAMPISI J., JANAKIRAMAN K., SHARPLESS N.E., DING S., FENG W. Clearance of senescent cells by ABT263 rejuvenates aged hematopoietic stem cells in mice. Nat. Med. 22 (1), 78, 2016.

60. BOERJAN W., RALPH J., BAUCHER M. Lignin biosynthesis. Annu. Rev. Plant Biol. 54 (1), 519, 2003.

61. MITTAL S., KUMARI N., SHARMA V. Differential response of salt stress on Brassica juncea: photosynthetic performance, pigment, proline, D1 and antioxidant enzymes. Plant Physiol. Biochem. 54, 17, 2012.

62. BIENERT G.P., CHAUMONT F. Aquaporin-facilitated transmembrane diffusion of hydrogen peroxide. Biochim. Biophys. Acta Biochim Biophys Acta. 1840 (5), 1596, 2014. 